\title{
Overin nadir tümörü: sklerozan stromal tümör
}

\author{
Rare tumor of the ovary: sclerosing stromal tumor
}

Soner Gök, Erkan Alataş, Ender Düzcan

Gönderilme tarihi: 06.05.2019

Kabul tarihi: 07.05.2020

Özet

Overin sklerozan stromal tümörü oldukça nadir görülen benign nonepitelyal bir tümördür. Hastalar genellikle pelvik ağrı, adet düzensizliği ve ele gelen kitle nedeniyle başvururlar. Bazen de hormonal olarak aktif olup androjen fazlalığı semptomlarına yol açabilmektedir. Tümörün radyolojik görüntüsü ve makroskopisindeki solid yapılar malign izlenim verebilmektedir. Kesin tanısı çoğunlukla postoperatif histolojik inceleme ile konulmaktadır. Biz bu olgu sunumunda oldukça nadir görülen sklerozan stromal tümörün klinik ve histopatolojik özelliklerini ve olgu yönetimini sunmayı amaçladık.

Anahtar kelimeler: Sklerozan stromal tümör, over, hiperandrojen.

Gök S, Alataş E, Düzcan E. Overin nadir tümörü: sklerozan stromal tümör. Pam Tıp Derg 2020;13:449-452.

\begin{abstract}
Sclerosing stromal tumor of the ovary is a very rare benign nonepithelial tumor. Patients usually present with pelvic pain, menstrual irregularity and palpable mass. Sometimes it is hormonal active and can cause symptoms of excess androgen. Radiological appearance of the tumor and solid structures in macroscopy can give a malignant impression. The definitive diagnosis is usually made by postoperative histological examination. In this case report, we aimed to present the clinical and histopathological features and case management of a very rare sclerosing stromal tumor.
\end{abstract}

Key words: Sclerosing stromal tumor, ovary, hyperandrogen

Gök S, Alataş E, Düzcan E. Rare tumor of the ovary: sclerosing stromal tumor. Pam Med J 2020;13:449-452.

\section{Giriş}

Overin seks kord-stromal tümörleri değişen klinik prezentasyon, morfolojik özellik ve prognozu ile heterojen bir neoplazm grubunu kapsayan nadir görülen nonepitelyal tümörlerdir. Stromal tümörler tüm benign over tümörlerinin $\% 0,5$ ile \%3,7ısini oluşturmaktadır ve yıllık insidansı 1 milyon kadın için 2,1 oranındadır [1]. Sklerozan stromal tümörler ise bu grubun \%2-6'sını oluşturan oldukça nadir görülen over tümörlerindendir [2]. Çoğunlukla unilateraldir ve 30 yaş altında görülmektedir. Hastalar genellikle pelvik ağrı, âdet düzensizliği ve ele gelen kitle nedeniyle başvururlar. Bazen hormonal olarak aktif olup androjen fazlalığı semptomlarına yol açabilmektedir. Tümörün radyolojik görüntüsü ve makroskopisindeki solid yapılar malign izlenim verebilmekte ve kesin tanısı çoğunlukla postoperatif histopatolojik inceleme ile konulmaktadır [3]. Bu olgumuzu oldukça nadir görülen sklerozan stromal tümörlerin preoperatif ve intraoperatif tanı yöntemleri ile benzer lezyonlardan ayrımında akılda tutulmasının önemi nedeniyle sunmaktayız.

\section{Olgu sunumu}

28 yaşında gravida 2 parite 2 olan hasta pelvik ağrı, yaklaşık 6 aydır devam eden menometroraji ve ele gelen adneksiyel kitle şikayetleri ile kliniğimize başvurdu. Yapılan fizik muayenede sol pelvik bölgede yaklaşık $7 \times 8$ cm'lik sert, mobil kitle tespit edildi. Transvajinal

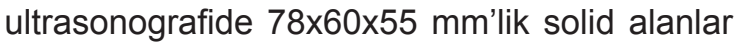
içeren heterojen kistik kitle ve batında minimal serbest sıvı görüldü. Hastanın Ca-125, Ca199 ve Ca15-3 gibi tümör belirteçleri normal

Soner Gök, Dr. Öğr. Üye. Pamukkale Üniversitesi Tıp Fakültesi Kadın Hastalıkları ve Doğum Anabilim Dalı, Denizli, Türkiye, e-posta: sonerrgok@ hotmail.com (orcid.org/0000-0001-8940-1879) (Sorumlu Yazar)

Erkan Alataş, Prof. Dr. Pamukkale Üniversitesi Tıp Fakültesi Kadın Hastalıkları ve Doğum Anabilim Dalı, Denizli, Türkiye, e-posta: erkanalatas@ hotmail.com (orcid.org/0000-0001-6423-5106)

Ender Düzcan, Prof. Dr. Özel A Tıbbi Laboravuvarı, İzmir, Türkiye, e-posta: seduzcan@gmail.com (orcid.org/0000-0001-57779279) 
düzeylerde değerlendirildi. Pelvik manyetik rezonans görüntülemede sol adneksiyal alanda kapsüle, lobüle konturlu, içerisinde kistik ve solid alanlar bulunan, postkontrast serilerde solid alanlarda heterojen yoğun boyanan 75x65x60 mm boyutlarında kitle görünümü rapor edildi. Bu tetkik sonuçları hastamızla detaylı bir şekilde görüşülüp tedavi seçenekleri hakkında bilgi verildi. Fertilitesini tamamlayan hastamız sol yumurtalığının alınmasını istedi. Tüm bu sonuçlar eşliğinde hastamız ameliyata alındı, intraoperatif gözlemde sol over kaynaklı, sınırları düzgün, kıvamı sert, yaklaşık $8 \mathrm{~cm}$ çapında kitle ve batın içerisinde minimal serbest sıvı izlendi. Hastamızın da isteği dikkate alınarak sol ooferektomi ve batın sıvı örneklemesi yapılıp patoloji bölümüne gönderildi. Sağ over ve pelvik yüzeyler olağan izlendi, lenfadenopati saptanmadı.

Patoloji laboratuvarında incelemesi yapılan materyalin makroskopik değerlendirmede $7,5 \times 5,5 \mathrm{~cm}$ boyutta sarı-beyaz renkte, iç yüz düzensiz ve kistik yapıda, duvar kalınlığı 1-1,5 $\mathrm{cm}$ boyutta yer yer turuncu renkte alanlar içeren materyal izlenmiştir. Materyalin mikroskopik incelemesinde iğsi hücrelerin storiform patern oluşturduğu alanlar ile bu alanlara eşlik eden, hafif hücresel atipinin de izlendiği sellüler odaklar saptandı. Tümör içinde dilate ve boynuzsu büyük vasküler yapılar dikkati çekti (Resim 1). Arada belirgin hyalinize stroma izlendi. Tümör dokusu iğsi myofibroblastik hücrelerden oluşmaktaydı (Resim 2). İmmünhistokimyasal incelemede vakuolize ve iğsi tümöral hücrelerde diffüz vimentin pozitifliği (Resim 3), luteinize hücrelerde sitoplazmik inhibin pozitifliği (Resim 4) görülmüş, EMA, CK7 ve CK20 negatif olarak rapor edilmiştir. Histokimyasal boyamada PAS spesifik boyanma izlenmemiştir. Batın yıkama mayi benign sitoloji olarak belirtilmiştir. Morfolojik ve immünohistokimyasal profil birlikte değerlendirildiğinde olgu sklerozan stromal tümör olarak değerlendirilmiştir.

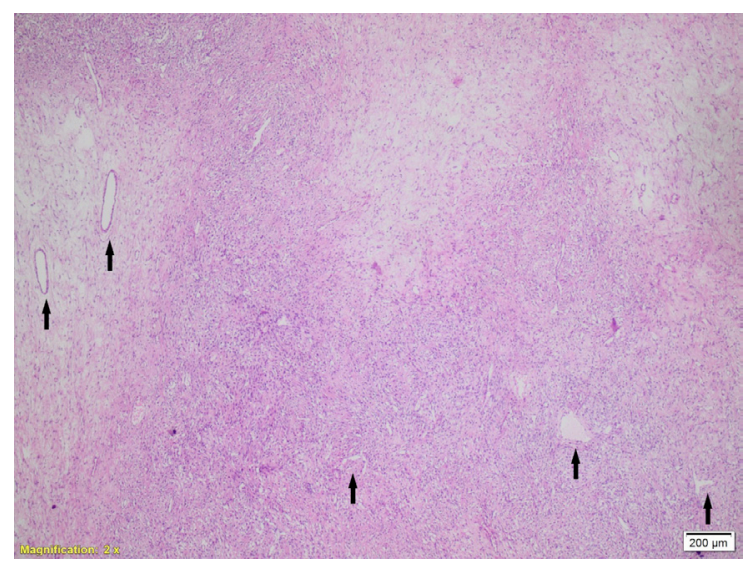

Resim 1. Hiperselüler ve ödemli hiposelüler alanlar içinde dilate ve boynuzsu şekilli vaskuler yapılar (okla işaretli) (HE, x200)

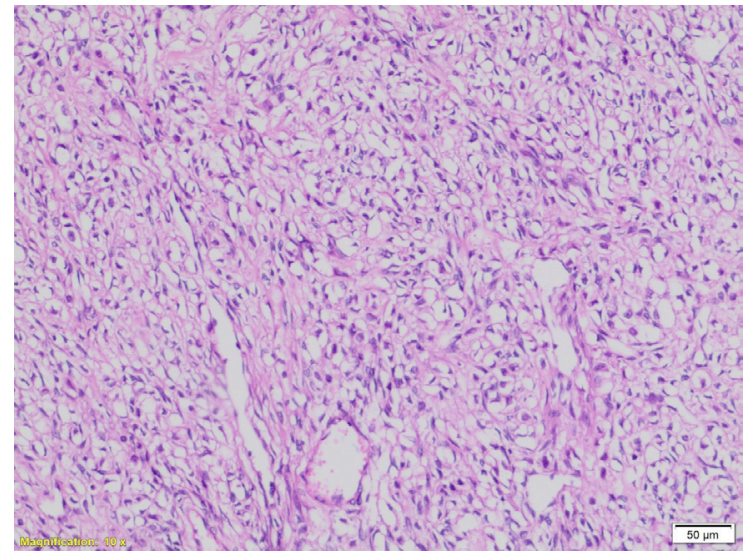

Resim 2. Sitoplazmik vakuolizasyon gösteren oval-yuvarlak stromal hücreler ve vaskuler yapılar (HE, x100)

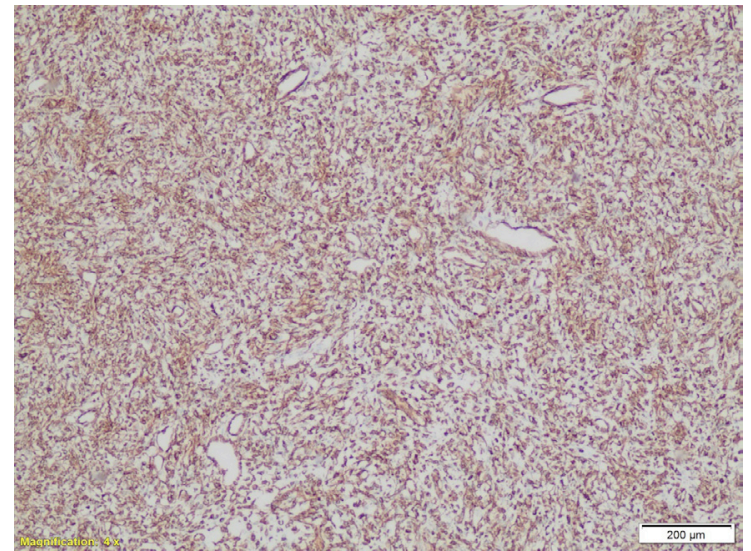

Resim 3. Vakuolize ve iğsi tümöral hücrelerde diffüz vimentin pozitifliği (x400) 


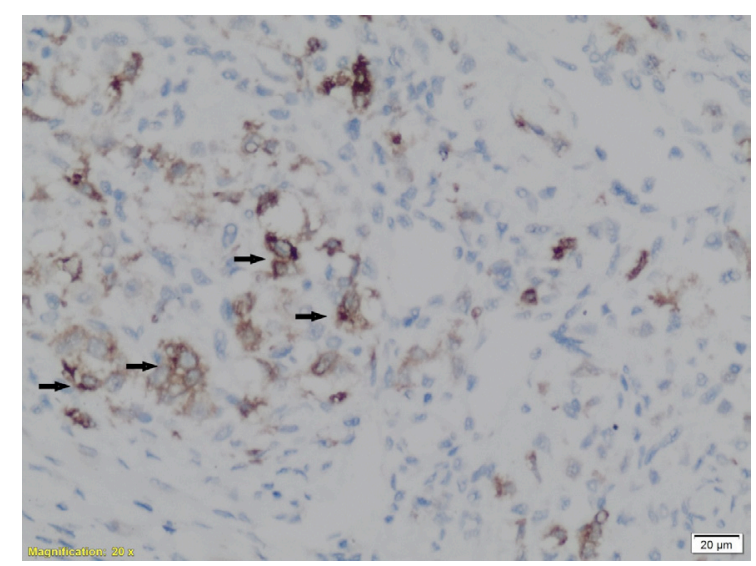

Resim 4. Luteinize hücrelerde sitoplazmik inhibin pozitifliği $(x 100)$

\section{Tartışma}

Sklerozan stromal tümörler diğer seks kord stromal tümörlerden klinik ve histopatolojik olarak farklı özellikler gösteren, oldukça nadir görülen, iyi prognozlu, öncelikli tedavisi cerrahi olan benign bir tümördür [4]. En sık 20'li ve 30 'lu yaşlarda görülür. Olgumuz bu tümör için literatürde belirtilen ortalama yaş grubundadır. Nadir olmakla birlikte adölesan ve pediatrik çağda veya postmenopozal dönemde de görülebilir. Literatürde bildirilen en küçük hasta 7 aylık bir kız çocuğunda puberte prekoks ile seyreden overin sklerozan stromal tümörüdür [5]. Genellikle unilateral olup, ender olarak bilateral olgular bildirilmiştir. Her iki overde yaklaşık olarak eşit oranlarda rastlanmakla birlikte, bizim olgumuzda sol overde izlenmiştir.

Olgular genellikle menstruasyon düzensizliği, menometroraji, pelvik ağrı ve yaklaşı $10 \mathrm{~cm}$ üzeri kitle varlığında nonspesifik bası şikayetleri ile başvururlar [6-8]. Bizim olgumuz da kronik pelvik ağrı, menometroraji ve pelviste ele gelen kitle şikayeti ile başvurdu. Sklerozan stromal tümörlerde genellikle tümör belirteçleri normal değerlerde olmakla birlikte, nadiren CA-125 yüksekliği bildirilmiştir [6-8]. Bizim olgumuzda da operasyon öncesi CA-125 değerleri normal sınırlar içerisinde tespit edilmiştir. Sklerozan stromal tümörler makroskopik olarak düzgün sınırı, yer yer kirli sarı renkte, ödem ve kistik alanların da görüldüğü solid kitle şeklindedir. Literatürde tamamen kistik olan olgu da bildirilmiştir [8]. Olgumuzun transvajinal ultrasonografisinde unilateral, 78x60×55 mm'lik düzgün sınırlı, solid alanlar içeren heterojen kistik kitle mevcuttu.

Sklerozan stromal tümörün ayırıcı tanısı̈önem taşımaktadır. Makroskopik görünümü nedeniyle malign tümörlerle, klinik ve histopatolojik olarak fibrom ve tekom ile karışabilmektedir. Sklerozan stromal tümörün daha erken yaşta görülmesi, bu tümörlerden ayrımında kolaylık sağlar. Ayrıca fibromlara kıyasla daha az asit mayisi eşlik eder. Sklerozan stromal tümördeki vakuoler stoplazmalı, nukleuslu hücreler taşlı yüzük hücrelerine benzemektedir. Bu da yanlış Krukenberg tümörü tanısına neden olabilmektedir. Ancak, Krukenberg tümörü sklerozan stromal tümörün aksine 6-7. dekatta görülür ve sıklıkla bilateraldir. Sklerozan stromal tümör vakuolllerde lipit içermesine rağmen, Krukenberg tümörü musin içermektedir [9]. Olgumuzda taşlı yüzük benzeri hücreler görülmüş, ancak çekirdekleri benign özellik göstermekte ve müsin içermemektedir.

Sonuç olarak, sklerozan stromal tümör nüks etmeyen, sıklıkla tek taraflı, over stromasından kaynaklı benign bir tümördür. Görüntülemede maligniteyi düşündürecek solid kitle varlığı nedeniyle ayırıca tanılar arasında mutlaka akılda tutulmalı ve imkân varsa intraoperatif histopatolojik değerlendirme yapılıp mümkün olan en konservatif operasyon tercih edilmelidir.

Çıkar ilişkisi: Yazarlar çıkar ilişkisi olmadığını beyan eder

\section{Kaynaklar}

1- Scully RE, Young RH, Clement PB. Tumors of the ovary mal developed gonads, fallopian tube and broad ligament. Atlas of Tumor Pathology. Third Series, Fascicle 23 Armed Forces Institute of Pathology, Washington 1998;527. https://doi.org/10.1002/ (SICI)1096-9896(199909)189:1\%3C145::AIDPATH420\%3E3.0.CO;2-F

2- Tavassoli FA, Fujii S, Mooney E, et al. Sex cord-stromal tumors in: tumours of the Breast and Female Genital organs. 5. ed. IARC Press: Lyon: 2003;152-153.

3- Iravanloo G, Nozarian Z, Sarrafpour B, Motahhary P. Sclerosing stromal tumor of the ovary. Arch Iran Med 2008;11:561-562.

4- Qureshi A, Raza A, Kayani N. The morphologic and immunohistoochemical spectrum of 16 cases of sclerosing stromal tumor of the ovary. Indian J Pathol Microbiol 2010;53:658-660. https://doi. org/10.4103/0377-4929.72017 
5- Aktaş S, Diniz G, Ortaç R, Ergin M, Erbay A. Sclerosing stromal tumor of the ovary with precocious puberty in a seven month old girl: case report. Turkiye Klinikleri J Gynecol Obst 2009;19:98-101

6- Şen N, Akbulut M, Çoban Ş, Yıldııım B, Düzcan SE. Sclerosing stromal tumor of the ovary, Ege Tıp Dergisi 2006;45:73-75.

7- Akbulut M, Şen Türk N, Aksoy Altınboga A, Soysal ME. Sclerosing stromal tumor in a postmenaouposal woman with an ovarian torsion. Pam Tıp Derg 2011;4:39-42.

8- Young RH, Clement PB. Sexcord-stromal and steroid cell and germ cell tumors of the ovary. In: Mills $S$, editor. Sternberg's Diagnostic Surgical Pathology, Volume II. 5th ed. Lippincott Williams and Wilkins 2010;23152316.

9- Russell P, Robboy SJ, Prat J. Ovarian sexcord-stromal and steroid cell tumors. In: Robboy's Pathology of the Female Reproductive Tract, 2nd ed. Churchill Living stone Elsevier 2009;703-705. 